\title{
EJSBS
}

The European Journal of Social \&

Behavioural Science

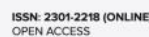

\section{AN ASSESSMENT OF UNIVERSITY STUDENTS' BOOK READING LEVELS AND PROBLEM SOLVING SKILLS}

\author{
Özcan Palavan ${ }^{\mathrm{a} *(\mathbb{D})}$, Duygu Çelik ${ }^{\mathrm{a}}$, Irem Yücel ${ }^{\mathrm{a}}$ \\ ${ }^{a}$ European University of Lefke, Cyprus
}

\begin{abstract}
The knowledge required to be acquired changes and increases with each passing day along with the developing technology and economy. In parallel with the increase in the knowledge required to be acquired, learning environments and mutual interaction are not enough anymore to acquire this knowledge. One of the most important ways to acquire knowledge is reading books. The studies conducted with pre-service teachers revealed that they mostly read newspapers followed by books and magazines. This study was carried out to assess the university students' book reading levels and the effect on their problem solving skills thereof. "Attitude Scale Towards Reading Habit" and "Problem Solving Inventory" were used to collect the research data. The results revealed a significant difference between the student groups created based on gender in attitudes towards reading in favor of the male students. Nevertheless, in terms of problem solving skills, a significant difference was found between the student groups created based on age in favor of the age group of under 20 years, and between the student groups created based on the type of high school which the student was graduated from, in favor of the students who were graduated from science and vocational high schools against students who were graduated from anatolian high schools. Lastly, a significant relationship ( $\mathrm{r}=.56)$ was found between the reading levels and the problem solving skills in the positive direction, which suggests that the higher the reading attitudes the higher the problem solving skills.
\end{abstract}

Keywords: Reading books, problem solving, university student 
https://doi.org/ 10.15405/ejsbs.310

eISSN: 2301-2218 / Corresponding Author: Özcan Palavan

Selection \& Peer-review under responsibility of the Editors

\section{Introduction}

People of today's world must have strong communication and critical thinking skills, if they will ever be successful. These skills allow one to ask the right questions, do research, and continously selfimprove in accordance with the changing social order. The knowledge required to be acquired changes and increases with each passing day along with the developing technology and economy. In parallel with the increase in the knowledge required to be acquired, learning environments and mutual interaction are not enough anymore to acquire this knowledge. Hence, in order to keep up with the constantly changing information, it is necessary to produce new methods and problem-solving strategies outside of education to assist with methods of formal learning. Accordingly, one of the most important ways to acquire knowledge is reading books. Reading is not only mumbling letters and syllables, but also the process of making sense of the words read. Reading habit is mostly acquired in the family setting as a result of a long process (Camp, 2007), and is improved at school (Alan, 2020; Applegate et al., 2014). In the context of Turkey, state's negative approach to reading books, particularly in times of emergency rule, negatively affected the reading habits of the Turkish people (Ortaş, 2014). Reading books has many positive effects on our daily life, including but not limited to on personal development and acquisition of many skills such as analytical skills, critical thinking skills, making logical connections and making the right decisions (Kahyaoğlu, 2011; Kuş \& Türkyılmaz, 2010; Yılmaz, 2012). These skills enable an individual to accurately define, research and solve any problem faced. A contemporary society can only be created based on individuals who are economically free, questioning, productive, inquisitive, decorated with critical thinking and problem solving skills, and gaining reading habit is the key to raising such individuals (Alan, 2020; Gömleksiz, 2004a; Phillip; 2020). It was demonstrated in a number of studies that individuals with thinking skills developed through reading can make better evaluations, produce creative solutions to problems, view events from a wider perspective, get rid of prejudices and become tolerant (Adalı, 2010; Güneş, 1999; Kartal \& Çağlar Özteke, 2010; Koç \& Müftüoğlu, 2008; Sever, 2004). Both Turkey and Northern Cyprus are not at the desired level in terms of reading levels when compared to other European countries. This can be attributed to the fact that there was no properly functioning education system in the Ottoman Empire, that the schooling could not develop sufficiently during the process that started with the Foundation of the Turkish Republic, and that the level of reading could not be brought to the desired level despite the education and training campaigns (Ortaş, 2014). This situation could improve if the society can be adequately educated and can grasp that reading means more than just uttering the letters. Turkish reading culture map (TOKH, 2011) reveals that only one out of every 4 individual in Turkey has the habit of reading, that people aged 65 and over generally do not read, whereas that children in the 7-14 age group read 12 or more books per year. These findings indicate that schools, especially elementary and middle schools, have a significant influence in reading books (Ortaş, 2014). The progress made in the problem solving skills of individuals by reading books is extremely valuable. Reading and comprehending what has been read are important steps in problem solving (Aydoğdu, 2008; Gooding, 2009; Olkun et al., 2010; Vilenius-Tuohimaa et al., 2008). Though is the first step to solving a problem, noticing the problem is usually the simplest of the steps to be taken in solving a problem. It is usually to produce solutions directed at solving the identified problem which is hard. As another finding that reveals the importance of reading in problem solving, Özsoy et al. (2015) determined that students with poor reading levels did not notice the 
https://doi.org/ 10.15405/ejsbs.310

eISSN: 2301-2218 / Corresponding Author: Özcan Palavan

Selection \& Peer-review under responsibility of the Editors

errors in their solutions, and that students with good reading levels were able to produce different solutions in their answers with confidence.

Taking into consideration that students and education can change in accordance with the spirit of the time, it will be useful to make various determinations from time to time on both the act of reading and problem solving skills. Seeking answers to certain questions and customize the education programs accordingly may assist in the development of the individuals in that regard. These questions include "Does encouraging reading at the elementary school level really work, if yes, is it maintained at the same level at the undergraduate education level or abandoned once the coercion disappears?", "What is the relationship between reading and problem solving?", etc. In this context, the aim of this study is to assess the university students' book reading levels and the effect on their problem solving skills thereof.

\section{Materials and Methods}

This study has been conducted as quantitative research using the screening technique, a technique suitable for collecting information common or different aspects of university students (Robson, 2017). Convenience sampling method was used for sample selection. The research data were collected from the 146 university students who were selected via the convenience sampling and agreed to participate in the research, using the "Attitude Scale Towards Reading Habit" and the "Problem Solving Inventory". The ttest, one-way analysis of variance (ANOVA) and the Scheffe's test were used to analyze the collected data.

\subsection{Attitude Scale Towards Reading Habit (ASTRH)}

In this study, the "Attitude Scale towards Reading Habit (ASTRH)" developed by Gömleksiz (2004b) was used to measure the attitudes of university students towards the habit of reading. The scale comprises 30 items and its Cronbach alpha reliability coefficient was calculated as 0.88 . Each of the items included in this 5-point Likert-type scale comprises five answer choices to choose from, which are, ' 5 ': Strongly Agree, '4': Agree, '3': Undecided '2': Disagree, and '1': Strongly Disagree”. Nine items in the scale are reversed items and they are scored reversely. The higher the overall score obtained from the scale the more positive the attitude towards book reading.

\subsection{Problem Solving Inventory (PSI)}

The problem solving inventory (PSI) was developed by Heppner and Petersen (1982) and adapted into Turkish by Şahin et al. (1993). Cronbach alpha consistency coefficient of the original and adapted version of the scale were calculated as .90 and .88, respectively. PSI is a Likert-type scale consisting of 35 items. Each of the items included in this 6-point Likert-type scale comprises six answer choices to choose from, which are, '6': Strongly Agree, '5': Moderately Agree, '4': Slightly Agree, '3': Slightly Disagree, '2': Moderately Disagree, and ' 1 ': Strongly Disagree. 14 items, that is the 1st, 2nd, 3rd, 4th, 11th, 13th, 14th, 15th, 17th, 21st, 25th, 26th, 30th and 34th items, are scored reversely. The lower the overall score obtained from the inventory the higher the problem solving skills, and vice versa (Şahin et al., 1993). 


\section{Results}

Attitudes of university students towards reading habit were analyzed according to gender using the t-test. The respective results are given in Table 1 .

Table 1. Distribution of ASTRH Scale Scores by Gender

\begin{tabular}{|c|c|c|c|c|c|}
\hline Gender & $\mathbf{N}$ & $\overline{\mathbf{x}}$ & s.d.* & $\mathbf{T}$ & $\mathbf{p}^{* *}$ \\
\hline Female Students & 79 & 69,25 & 11,87 & \multirow[t]{2}{*}{$-2,051$} & \multirow[t]{2}{*}{$0,042 * * *$} \\
\hline Male Students & 67 & 74,66 & 19,55 & & \\
\hline
\end{tabular}

Note: ${ }^{*}$ s.d.: standard deviation, ${ }^{* *}$ p.: probability, ${ }^{* * *} \mathrm{p}<0,05$

The analysis of the attitudes of university students towards reading habit according to the gender using the t-test revealed a significant difference between the student groups in favor of the male students $\{\mathrm{t}=-2,051 ; \mathrm{p}<0,05\}$. The mean overall ASTRH scale score obtained by the students were calculated as 74.66 and 69.25 for male and female student groups, respectively.

Attitudes of university students towards reading habit were analyzed according to the educational level of their mothers using the one-way ANOVA test. The respective results are given in Table 2.

Table 2. Distribution of ASTRH Scale Scores by the Educational Level of the Mother

\begin{tabular}{|c|c|c|c|c|c|}
\hline \multicolumn{3}{|c|}{ Educational Level of the Mother* } & $\mathbf{N}$ & $\overline{\mathbf{x}}$ & s.d. ${ }^{* *}$ \\
\hline \multicolumn{3}{|c|}{ Elementary School } & 33 & 74.45 & 23.13 \\
\hline \multicolumn{3}{|c|}{ Middle School } & 39 & 71.59 & 9.14 \\
\hline \multicolumn{3}{|l|}{ High School } & 51 & 72.02 & 15.78 \\
\hline \multicolumn{3}{|l|}{ University } & 23 & 67.43 & 13.29 \\
\hline \multicolumn{3}{|l|}{ Total } & 146 & 71.73 & 16.04 \\
\hline Variance & $\mathbf{S S}^{* * *}$ & $d f^{* * * *}$ & & $\mathbf{F}^{* * * * * *}$ & $\mathbf{p}^{* * * * * * *}$ \\
\hline Inter-Group & 674.332 & 3 & & .872 & .457 \\
\hline Intra-Group & 36616.250 & 142 & & & \\
\hline Total & 37290.582 & 145 & & & \\
\hline
\end{tabular}

According to Table-2, the mean overall ASTRH scale scores obtained by the students were calculated as $74.45,71.59,72.02$ and 67.43 for university students, whose mothers graduated from elementary school, middle school, high school and university, respectively. It is noteworthy that the students' reading attitude scores were found to be inversely proportional with the educational level of their mothers, albeit not statistically significantly $\{\mathrm{t}=.872 ; \mathrm{p}>.05\}$.

Attitudes of university students towards reading habit were analyzed according to the educational level of their fathers using the one-way ANOVA test. The respective results are given in Table 3. 
https://doi.org/ 10.15405/ejsbs.310

eISSN: 2301-2218 / Corresponding Author: Özcan Palavan

Selection \& Peer-review under responsibility of the Editors

Table 3. Distribution of ASTRH Scale Scores by the Educational Level of the Father

\begin{tabular}{|c|c|c|c|c|}
\hline \multicolumn{2}{|c|}{ Educational Level of the Father } & $\mathbf{N}$ & $\overline{\mathbf{x}}$ & s.d. ${ }^{* *}$ \\
\hline \multicolumn{2}{|c|}{ Elementary School } & 41 & 71.49 & 16.62 \\
\hline \multicolumn{2}{|c|}{ Middle School } & 32 & 68.78 & 11.02 \\
\hline \multicolumn{2}{|l|}{ High School } & 42 & 74.31 & 17.54 \\
\hline \multicolumn{2}{|l|}{ University } & 31 & 71.61 & 17.60 \\
\hline \multicolumn{2}{|l|}{ Total } & 146 & 71.73 & 16.04 \\
\hline Variance & $\mathbf{S S}^{* * *}$ & $\mathrm{df}^{* * * *}$ & $\mathbf{F}^{* * * * *}$ & $\mathbf{p}^{* * * * * *}$ \\
\hline Inter-Group & 560.539 & 3 & \multirow{3}{*}{.722} & \multirow{3}{*}{.540} \\
\hline Intra-Group & 36730.044 & 142 & & \\
\hline Total & 37290.582 & 145 & & \\
\hline
\end{tabular}

Note: ${ }^{*}$ as of last school having graduated from, ${ }^{* *}$ s.d.: standard deviation, ${ }^{* * *}$ SS: sum of squares, ${ }^{* * * *}$ df: degrees of freedom, ${ }^{* * * * *} \mathrm{~F}$ : value on the F distribution, ${ }^{* * * * * *}$ p: probability

According to Table-3, the mean overall ASTRH scale scores obtained by the students were calculated as $71.49,68.78,74.31$ and 71.61 for university students, whose fathers graduated from elementary school, middle school, high school and university, respectively. The mean overall ASTRH scale score of the students, whose fathers were high-school graduates, were found to be higher than other groups, albeit not statistically significantly $\{\mathrm{t}=.722 ; \mathrm{p}>.05\}$.

Attitudes of university students towards reading habit were analyzed according to their age groups using the one-way ANOVA test. The respective results are given in Table 4.

Table 4. Distribution of ASTRH Scale Scores by the Age Groups

\begin{tabular}{|c|c|c|c|c|c|c|}
\hline Age Groups & $\mathbf{N}$ & & $\overline{\mathbf{x}}$ & & s.d. ${ }^{*}$ & \\
\hline under 20 years old & 47 & & 67.91 & & 13.50 & \\
\hline between 20 and 25 years old & 62 & & 75.20 & & 19.89 & \\
\hline over 25 years old & 37 & & 70.75 & & 9.57 & \\
\hline Total & 146 & & 71.73 & & 16.04 & \\
\hline Variance & & $\mathbf{S S}^{* *}$ & & $\mathbf{d f}^{* * *}$ & $\mathbf{F}^{* * * *}$ & $\mathbf{p}^{* * * * * *}$ \\
\hline Inter-Group & & 1469.838 & & 2 & \multirow{3}{*}{2.934} & \multirow{3}{*}{.056} \\
\hline Intra-Group & & 35820.745 & & 143 & & \\
\hline Total & & 37290.582 & & 145 & & \\
\hline
\end{tabular}

According to Table-4, the mean overall ASTRH scale scores obtained by the students were calculated as 67.91, 75.20, and 70.75 for university students, whose under 20 years old, between 20 and 25 years old, and over 25 years old, respectively. The differences between the mean scale scores of the student groups created based on age were not statistically significant $\{t=2.934 ; \mathrm{p}>.05\}$.

Attitudes of university students towards reading habit were analyzed according to the type of high school they were graduated from using the one-way ANOVA test. The respective results are given in Table 5 . 
https://doi.org/ 10.15405/ejsbs.310

eISSN: 2301-2218 / Corresponding Author: Özcan Palavan

Selection \& Peer-review under responsibility of the Editors

Table 5. Distribution of ASTRH Scale Scores by the Type of High School Having Graduated From

\begin{tabular}{|c|c|c|c|c|}
\hline Type of High School & $\mathbf{N}$ & $\overline{\mathbf{x}}$ & s.d.* & \\
\hline Anatolian High School & 96 & 73.03 & 15.78 & \\
\hline Vocational High School & 31 & 71.32 & 18.24 & \\
\hline Science High School & 19 & 65.84 & 12.51 & \\
\hline Total & 146 & 71.73 & 16.04 & \\
\hline Variance & $\mathbf{S S}^{* * *}$ & $d f f^{* * *}$ & $\mathbf{F}^{* * * * *}$ & $\mathbf{p}^{* * * * * * *}$ \\
\hline Inter-Group & 826.375 & 2 & & \\
\hline Intra-Group & 36464.207 & 143 & 1,620 & ,201 \\
\hline Total & 37290.582 & 145 & & \\
\hline
\end{tabular}

According to Table-5, the mean overall ASTRH scale scores obtained by the students were calculated as $73.03,71.32$, and 65.84 for university students, who were graduated from anatolian high school, vocational high school, and science high school, respectively. The mean overall ASTRH scale score of the students, who were graudated from science high schools, were found to be lower than other groups, albeit not statistically significantly $\{t=1.620 ; \mathrm{p}>.05\}$.

Problem solving inventory scores of university students were analyzed according to gender using the t-test. The respective results are given in Table 6 .

Table 6. Distribution of PSI Scores by Gender

\begin{tabular}{llllll}
\hline Gender & $\mathbf{N}$ & $\overline{\mathbf{x}}$ & s.d. $^{*}$ & $\mathbf{T}$ & $\mathbf{p}^{* * *}$ \\
\hline Female Students & 79 & 98,11 & 18,44 & .268 & .789 \\
\hline Male Students & 67 & 97,11 & 22,35 & & \\
\hline
\end{tabular}

Note: ${ }^{*}$ s.d.: standard deviation, ${ }^{* *}$ p.: probability

The analysis of the PSI scores according to the gender using the t-test did not reveal a significant difference between the student groups $\{t=.268 ; \mathrm{p}>.05\}$. The mean overall PSI scores obtained by the students were calculated as 97.11 and 98.11 for male and female students, respectively.

Problem solving inventory scores of university students were analyzed according to the educational level of their mothers using the one-way ANOVA test. The respective results are given in Table 7.

Table 7. Distribution of PSI Scores by the Educational Level of the Mother

\begin{tabular}{llll}
\hline Educational Level of the Mother* & $\mathbf{N}$ & $\mathbf{x}$ & s.d.** $^{*}$ \\
\hline Elementary School & 33 & 98.45 & 26.00 \\
\hline Middle School & 39 & 100.39 & 14.23 \\
\hline High School & 51 & 98.75 & 19.53 \\
\hline University & 23 & 89.74 & 20.60 \\
\hline Total & 146 & 97.70 & 20.27 \\
\hline
\end{tabular}




\begin{tabular}{|c|c|c|c|c|}
\hline Variance & $\mathbf{S S}^{* * * *}$ & $\mathbf{d f}^{* * * *}$ & $\mathbf{F}^{* * * * * *}$ & $\mathbf{p}^{* * * * * * *}$ \\
\hline Inter-Group & 1813.206 & 3 & & \\
\hline Intra-Group & 57735.534 & 142 & 1.487 & .221 \\
\hline Total & 59548.740 & 145 & & \\
\hline
\end{tabular}

According to Table-7, the mean overall PSI scores obtained by the students were calculated as 98.45 , $100.39,98.75$ and 89.74 for university students, whose mothers graduated from elementary school, middle school, high school and university, respectively. The analysis of the PSI scores obtained by the students according to the educational level of their mothers did not reveal a significant difference between the groups $\{t=1,487 \mathrm{p}>.05\}$.

Problem solving inventory scores of university students were analyzed according to the educational level of their fathers using the one-way ANOVA test. The respective results are given in Table 8 .

Table 8. Distribution of PSI Scores by the Educational Level of the Father

\begin{tabular}{|c|c|c|c|c|}
\hline \multicolumn{2}{|c|}{ Educational Level of the Father* } & $\mathbf{N}$ & $\bar{x}$ & s.d. ${ }^{* *}$ \\
\hline \multicolumn{2}{|c|}{ Elementary School } & 41 & 98.80 & 19.16 \\
\hline \multicolumn{2}{|c|}{ Middle School } & 32 & 94.37 & 19.28 \\
\hline \multicolumn{2}{|l|}{ High School } & 42 & 96.54 & 22.38 \\
\hline \multicolumn{2}{|l|}{ University } & 31 & 101.22 & 19.97 \\
\hline \multicolumn{2}{|l|}{ Total } & 146 & 97.70 & 20.27 \\
\hline Variance & $\mathbf{S S}^{* * * *}$ & $\mathbf{d f}^{* * * *}$ & $\mathbf{F}^{* * * * *}$ & $\mathbf{p}^{* * * * * * *}$ \\
\hline Inter-Group & 844.977 & 3 & & \\
\hline Intra-Group & 58703.763 & 142 & .681 & .565 \\
\hline Total & 59548.740 & 145 & & \\
\hline
\end{tabular}

According to Table-8, the mean overall PSI scores obtained by the students were calculated as 98.80 , 94.37, 96.54 and 101.22 for university students, whose mothers graduated from elementary school, middle school, high school, and university, respectively. The analysis of the PSI scores obtained by the students according to the educational level of their fathers did not reveal a significant difference between the groups $\{t=685 ; p>.05\}$. Contrary to the distribution of the mean overall PSI scores obtained by the students by the educational level of their mothers, however, the mean overall PSI scores obtained by the students were found to have increased as the educational level of their fathers increased, albeit not statistically significantly.

Problem solving inventory scores of university students were analyzed according to their age groups using the one-way ANOVA test. The respective results are given in Table 9. 
https://doi.org/ 10.15405/ejsbs.310

eISSN: 2301-2218 / Corresponding Author: Özcan Palavan

Selection \& Peer-review under responsibility of the Editors

Table 9. Distribution of PSI Scores by the Age Groups

\begin{tabular}{|c|c|c|c|c|c|}
\hline Age Groups & & $\mathbf{N}$ & \multicolumn{2}{|c|}{$\overline{\mathbf{x}}$} & s.d. ${ }^{*}$ \\
\hline under 20 yea & & 47 & \multicolumn{2}{|c|}{91.68} & 21.24 \\
\hline between 20 a & ld (2) & 62 & \multicolumn{2}{|c|}{103.56} & 18.41 \\
\hline over 25 years & & 37 & \multicolumn{2}{|c|}{95.51} & 19.79 \\
\hline Total & & 146 & \multicolumn{2}{|c|}{97.70} & 20.27 \\
\hline Variance & $\mathbf{S S}^{* *}$ & $d f^{* * *}$ & $\mathbf{F}^{* * * * *}$ & $\mathbf{p}^{* * * * * *}$ & difference \\
\hline Inter-Group & 4012.042 & 2 & \multirow{3}{*}{5.165} & \multirow{3}{*}{$.007^{* * * * * * *}$} & \multirow{3}{*}{$2-1$} \\
\hline Intra-Group & 55536.698 & 143 & & & \\
\hline Total & 59548.740 & 145 & & & \\
\hline
\end{tabular}

According to Table-9, the mean overall PSI scores obtained by the students were calculated as 91.68, 103.56, and 95.51 for university students, whose under 20 years old, between 20 and 25 years old, and over 25 years old, respectively. One-way ANOVA analysis $\{t=.007 \mathrm{p}<.05\}$ and The Scheffe's test revealed a significant difference between the group of students under 20 years old and the group of students between 20 and 25 years old in favor of the group of students under 20 years old, considering that the lower the score the higher the problem solving skills.

Problem solving inventory scores of university students were analyzed according to the type of high school they were graduated from using the one-way ANOVA test. The respective results are given in Table 10.

Table 10. Distribution of PSI Scores by the Type of High School Having Graduated From

\begin{tabular}{|c|c|c|c|c|c|}
\hline \multicolumn{2}{|c|}{ Type of High School } & $\mathbf{N}$ & $\overline{\mathbf{x}}$ & \multicolumn{2}{|c|}{ s.d. ${ }^{*}$} \\
\hline \multicolumn{2}{|c|}{ Anatolian High School (1) } & 96 & 101.25 & \multicolumn{2}{|c|}{20.45} \\
\hline \multicolumn{2}{|c|}{ Vocational High School (2) } & 31 & 90.87 & \multicolumn{2}{|c|}{18.67} \\
\hline \multicolumn{2}{|c|}{ Science High School (3) } & 19 & 90.89 & \multicolumn{2}{|c|}{17.97} \\
\hline \multicolumn{2}{|l|}{ Total } & 146 & 97.70 & \multicolumn{2}{|c|}{20.27} \\
\hline Variance & $\mathbf{S S}^{* *}$ & $\mathrm{df}^{* * *}$ & $\mathbf{F}^{* * * * *}$ & $\mathbf{p}^{* * * * * *}$ & difference \\
\hline Inter-Group & 3535.466 & 2 & 4.513 & \multirow{3}{*}{$.013^{* * * * * * *}$} & \multirow{3}{*}{$\begin{array}{l}1-2 \\
1-3\end{array}$} \\
\hline Intra-Group & 56013.273 & 143 & & & \\
\hline Total & 59548.740 & 145 & & & \\
\hline
\end{tabular}

According to Table-10, the mean overall PSI scores obtained by the students were calculated as 10125, 90.87, and 90.89 for university students, who were graduated from anatolian high school, vocational high school, and science high school, respectively. The one-way ANOVA analysis revealed a significant difference between the groups $\{t=.013 \mathrm{p}<.05\}$. Additionally, the Scheffe's test, which was conducted to find out the groups that have the said significant difference in between, revealed that the difference was between the PSI scores of the students who graduated from vocational high school or science high school, 
https://doi.org/ 10.15405/ejsbs.310

eISSN: 2301-2218 / Corresponding Author: Özcan Palavan

Selection \& Peer-review under responsibility of the Editors

and the PSI scores of the students who graduated from anatolian high school, in favor of the former. In other words, it was determined that the university students graduated from anatolian high school were weaker than the other students in terms of problem solving.

The analysis of the relationship between university students' attitudes towards reading habit, i.e. ASTRH scores, and their problem solving skill levels, i.e. PSI scores, through the calculation of the Pearson product-moment correlation coefficient, i.e. Pearson's correlation coefficient, revealed a moderately positive linear relationship between the two score sets. The respective findings are given in Table 11.

Table 11. The Relationship between ASTRH ${ }^{*}$ and PSI $^{* *}$ Scores

\begin{tabular}{lcc}
\hline Pearson's Correlation & & \\
\hline Attitude Scale Towards Reading Habit & $\mathrm{n}$ & $\mathrm{r}$ \\
\cline { 2 - 3 } Problem Solving & 146 & $.560^{\text {*** }}$
\end{tabular}

Note: ${ }^{*}$ ASTRH: Attitude Scale Towards Reading Habit, ${ }^{* *}$ PSI:Problem Solving Inventory, ${ }^{* * *}$ Correlation is significant at the 0.01 level (2-tailed).

As a result, a significant relationship $(\mathrm{r}=.56)$ was found between the attitudes towards reading habit and the problem solving skills in the positive direction level between reading a book and problem solving skills.

\section{Discussion and Conclusion}

The findings of this study revealed a significant difference between the groups of university students created based on gender in attitudes towards reading in favor of the male students. To the contrary, in the study conducted by Ar1 and Demir (2013) with the university students enrolled in the Department of Primary Education of Faculty of Education at Çanakkale Onsekiz Mart University of Turkey, as well as in the study conducted by Can et al. (2016), female students were found to have higher levels of attitudes towards reading than male students. Similarly, females were found to have higher levels of attitudes towards reading than males in studies conducted by Aral and Aktaş (1997), Coles and Hall (2002), Saracaloğlu et al. (2007), Odabaş et al. (2008) and Ürün Karahan (2015). On the other hand, Sevgi and Karakaya (2021) did not find any difference between the students' reading habits in terms of gender. In parallel, there are other studies in which it was determined that gender has no effect on the attitudes towards reading (Baydilek et al., 2018; Bozpolat, 2010; Çeçen \& Alver, 2011). Many variables might have contributed to such results. Among these variables, the effect of the environment, especially the family, is noteworthy. Nevertheless, in this study, no difference was found between the groups of university students created based on the educational levels of their mothers or fathers in attitudes towards reading. Similarly, Odabaş et al. (2008) and Arı and Demir (2013) also did not find any difference between student groups created based on the educational levels of their mothers or fathers in reading habits. On the other hand, in the study conducted by Durualp et al. (2013), it was determined that students' attitudes towards reading significantly differed based on the status of having parents that read books. In the study conducted by Aric1 (2005) with secondary school students, $57.3 \%$ of the students said that they have taken their teachers as their role models in respect of reading habits, as compared to the $17.9 \%$ and $13.4 \%$ of the students who said have taken their mother and fathers as their role models in respect of reading habits, respectively. In the study conducted by Özdemirci (1990), in which the factors related to reading and the act of reading were investigated, it was determined that parents of the $60 \%$ of the participants do not read books, and that $51 \%$ of the participants 
https://doi.org/ 10.15405/ejsbs.310

eISSN: 2301-2218 / Corresponding Author: Özcan Palavan

Selection \& Peer-review under responsibility of the Editors

did not have a bookcase at home. Durualp et al. (2013) emphasized the importance of parents' educational levels and stated that children growing up in families that do not possess a reading culture do not have sufficient reading skills. Similar results were reported in many other studies (Arıc1, 2005; Keleş, 2006; Molfese et al., 2003; Odabaş et al., 2008). The fact that parents' educational levels were found not to have significantly affected the reading habits of their children in these studies suggest that they do not set a good example for their children in that respect. In-depth qualitative studies may provide clearer results in cases where quantitative studies produce conflicting results such as in relation to the effect of parents on reading habits of their children.

In this study, there was no significant difference between the groups of university students created based on age and the type of high school which the student was graduated from in terms of attitudes towards reading. This is contrary to the expectation that the students enrolled in or graduated from science high schools in particular and anatolian high schools would have higher reading levels than those enrolled in or graduated from vocational high schools and that the reading levels would increase gradually come university years. These results suggest that the improvement detected in the reading levels of children of 714 years old within the framework of the Turkey Reading Culture Map Project (2011) was not maintained afterwards, that the type of school student enrolled in or has graduated from has only a temporary impact on students' reading levels, and hence that an intrinsic willingness to read books is the key to gaining permanent reading habits.

Among other factors not investigated in this study on reading is the screen time. Yavuzer (2013) found that reading habit has weakened as more time was put in watching the television, a result which he pointed out that may cause the children to be prone to violence in the future. In this respect, further studies are needed to determine the relationship between the attitudes towards reading and predisposition to violence.

In terms of problem solving skills, in this study, no statistically significant difference was found between male and female university students. Similar results were obtained in studies conducted by Bal (2011), Pehlivan and Konukman (2004) and Sevgi and Karakaya (2021). However, there are also studies available in the literature which reported gender as a significant variable in problem solving skills (Çelik Ercoşkun \& Köse, 2014; Gencel, 2015; Serin, 2006).

Additionally, in this study, no statistically significant difference was found between the groups of university students created based on the educational levels of their mothers or fathers in terms of problem solving skills. Similarly, Aslan and Sağır (2012) and Serin and Derin (2008) did not find any statistically significant relation between the educational levels of students' mothers or fathers and students' problem solving skills. Çağlayan et al. (2008), on the other hand, did not find any statistically significant relation between the educational levels of students' mothers and students' problem solving skills, yet found a statistically significant relation between the educational levels of students' fathers and students' problem solving skills. Lastly, in the study conducted by Ünüvar (2003), it was determined that the scores obtained from all sub-dimensions of the problem solving inventory differed significantly according to the students' mothers' educational level.

In terms of the relation between the problem solving skills and the age groups, no statistically significant difference was found in this study between the groups of students created based on age, except for the significant difference found between the group of students under 20 years old and the group of 
students between 20 and 25 years old in favor of the group of students under 20 years old. There are other studies in which problem solving skills were found to have differed according to age groups. In one of these studies, Karslı (2019) found that the problem solving skills increased significantly with age. It is difficult to infer for sure based on these results whether age has an effect on problem solving, yet there is a high probability that there may be differences in problem solving skills between the students that are in different stages of adolescence and in the transition to the abstract operational period. This might just be the reason for the relevant finding of this study in that no statistically significant difference was found between the groups of students created based on age with the exception of only one difference, since the students investigated within the scope of this study had already completed the said transitional stages.

Furthermore, a significant difference was found between the student groups created based on the type of high school which the student was graduated from, in favor of the students who were graduated from anatolian high schools. This result may be attributed to the fact that the education given to the students who graduate from anatolian high schools is more general in nature and is thus not sufficient to develop their problem-solving skills. As compared to the anatolian high schools, the education in vocational high schools involves practical applications of technical knowledge that can be used to produce solutions to problems, whereas the education in science high schools involves high-level thinking skills.

Lastly, a significant relationship ( $\mathrm{r}=.56)$ was found between the reading levels and the problem solving skills in the positive direction, which suggests that the higher the reading attitudes the higher the problem solving skills. Similarly, in the study conducted by Vilenius-Tuohimaa et al. (2008) a positive correlation $(\mathrm{r}=0.67)$ was found between the reading comprehension levels and problem solving skills, and in the study conducted by Sevgi and Karakaya (2021), a significant relationship $(r=0.124)$ was found between the reading habits and the problem solving skills in the positive direction. On the other hand, Proudfoot (2016) did not find any correlation between the reading comprehension levels and problem solving skills, and Karakılıç and Arslan (2019) did not find any significant relationship between the reading levels and the problem solving skills.

\section{Recommendations}

Based on the findings of this study, it is recommended to add certain elective courses to the curriculum that would arise pre-service teachers' interest in reading. In addition, reading $\&$ review projects and assignments can be given to pre-service teachers and students in primary and secondary education. The help of parents can be sought in the efforts to increase the attitudes of students towards reading starting from primary schools. Accordingly, it can be requested of the parents to read together with their children and to reenact the stories read. Parents can be provided trainings within the framework of school-parent associations so that they can serve as a good role model to their children and inculcate the habit of reading to them. Number of projects, which will increase students' access to books, such as reading books at the bus stop, reading books while shopping, etc. should be increased. Pre-service teachers can be encouraged to take part in these projects and serve as a good role model to the children.

\section{Acknowledgements}

The author(s) declare that there is no conflict of interest. 


\section{References}

Adalı, O. (2010). Etkileşimli ve eleştirel okuma teknikleri [Interactive and critical reading techniques] (1st. ed.). Toroslu Publishing.

Alan, Y. (2020). Türkiye'deki Üniversite Öğrencilerinin Kitap Okuma Profilleri [Reading Profiles of University Students in Turkey]. Söylem Filoloji Dergisi, 5(1), 278-303. https://doi.org/10.29110/soylemdergi.720634

Applegate, A. J., Applegate, M. D., Mercantini, M. A., McGeehan, C. M., Cobb, J. B., DeBoy, J. R., Modla, V. B., \& Lewinski, K. E. (2014). The Peter effect revisited: Reading habits and attitudes of college students. Literacy Research and Instruction, 53(3), 188-204. https://doi.org/10.1080/19388071.2014.898719

Aral, N., \& Aktaş, Y. (1997). Çocukların televizyon ve diğer etkinliklere harcadıkları sürenin incelenmesi [Examining the time children spend on television and other activities]. Hacettepe Üniversitesi Ë̆itim Fakültesi Dergisi, 13, 99-105

Arı, E., \& Demir, M. K. (2013). İlköğretim bölümü öğretmen adaylarının kitap okuma alışkanlıklarının değerlendirilmesi [Assessing Reading Habits of Student Teachers' at Department of Elementary Education]. Ana Dili Eğitimi Dergisi, 1(1), 116-128. https://doi.org/10.16916/aded.16025

Arıcı, A. F. (2005). İlköğretim ikinci kademe öğrencilerinin okuma durumları [Reading status of secondary school students] [Unpublished PhD Dissertation]. Erzurum, Atatürk Üniversitesi.

Aslan, O., \& Sağır, Ş. U. (2012). Fen ve Teknoloji Öğretmen Adaylarının Problem Çözme Becerileri [Problem Solving Skills of Science and Technology Teacher Candidates]. Journal of Turkish Science Education, 9(2) 82-94. https://hdl.handle.net/20.500.12452/1990

Aydoğdu, M. (2008). Matematikte öğrencilere problem çözme yeteneğinin kazandırılması [Redounding Problem Solving Skill to Students In Mathematics]. Physical Sciences, 3(4), 588-596.

Bal, M. (2011). Okul öncesi öğretmenlerinin problem çözme becerileri ile eleştirel düşünme eğilimleri arasındaki ilişkinin incelenmesi [Examining the relationship between preschool teachers' problem solving skills and critical thinking dispositions (Master's Thesis)]. Abant İzzet Baysal Üniversitesi Sosyal Bilimler Enstitüsü, Bolu.

Baydilek, B. N., Altay, B., \& Saracaloğlu, A. S. (2018). Okul öncesi, rehberlik ve psikolojik danışmanlık ile resim-iş programı öğrencilerinin üst bilişsel öğrenme stratejilerini yordayan değişkenlerin belirlenmesi [Determination of The Variables That Predict the Metacognitive Learning Strategies of The Students of the Preschool, Guidance and Psychological Counseling, and Art Program]. Kastamonu Education Journal, 26(3), 707-720.

Bozpolat, E. (2010). Öğretmen adaylarının okuma alışkanlığına ilişkin tutumlarının değerlendirilmesi (Cumhuriyet Üniversitesi Eğitim Fakültesi Örneği) [ Evaluation of pre-service teachers' attitudes towards reading habits (Cumhuriyet University Faculty of Education Example)]. Journal of World of Turks/Zeitschrift für die Welt der Türken, 2(1),411-428.

Camp, D. (2007). Who's reading and why: reading habits of lst grade through graduate students. Reading Horizons Journal, 47(3), 251-268.

Can, A., Deniz, E., \& Çeçen, M. (2016). Ortaokul öğrencilerinin okuma tutumları [Reading attitudes of middle school students]. International Periodical for the Languages, Literature and History of Turkish or Turkic, 11(3), 645-660. https://doi.org/10.7827/TurkishStudies.9311

Coles, M., \& Hall, C. (2002). Gendered reading: Learning from children's reading choices, Journal of Research in Reading, 25(1), 96-108. https://doi.org/10.1111/1467-9817.00161

Çağlayan, H. S., Taşğın, Ö., \& Yıldız, Ö. (2008). Spor yapan lise öğrencilerinin problem çözme becerilerinin çeşitli değişkenler açısından incelenmesi [Analyzing Skills of Solving Problems of High Schools Students Who are Doing Sports From Different Angles Considering Variables]. Beden $\begin{array}{lllll}\text { Eğitimi ve Bilimleri } & \text { Spor }\end{array}$ https://dergipark.org.tr/en/pub/bsd/issue/53631/715491

Çeçen, M. A., \& Alver, M. (2011). Türkçe öğretmeni adaylarının üst bilişsel okuma stratejilerini kullanma düzeyleri (Giresun Üniversitesi örneği) [Usage level of Metacognitive Reading Strategies of Turkish-Language Teacher Candidates (Giresun University Case)]. Karadeniz Sosyal Bilimler Dergisi, 3(5), 39-56.

Çelik, E. N., \& Köse, E. (2014). Investigation of self-regulation and problem solving skills of prospective elementary teachers. International Online Journal of Educational Sciences, 6(2), 413- 428. 
Durualp, E., Çiçekoğlu, P., \& Durualp, E. (2013). Sekizinci Sınıf Öğrencilerinin Kitap Okumaya Yönelik Tutumlarının İnternet ve Kitap Okuma Alışkanlıkları Açısından İncelenmesi [Examination of the Attitude of Reading Students in the $8^{\text {th }}$ Grades in Terms of Use Internet and Reading Habits]. Uluslararası Türkçe Edebiyat Kültür Eğitim (TEKE) Dergisi, 2(1), 115-132. https://dergipark.org.tr/en/pub/teke/issue/12845/155638

Gencel, E. İ. (2015). Learning styles and problem solving skills of Turkish prospective teachers. International Journal of Progressive Education, 11(2) 39-56

Gooding, S. (2009). Children's difficulties with mathematical Word problems. Proceedings of the British Society for Research into Learning Mathematics, 29(3), 31-36.

Gömleksiz, M. N. (2004a). Geleceğin öğretmenlerinin kitap okumaya ilişkin görüşlerinin değerlendirilmesi (Fırat Üniversitesi Eğitim Fakültesi örneği) [Evaluation of the opinions of future teachers about reading books (Frrat University Faculty of Education example)]. Yüzüncü Yll Üniversitesi Eğitim Fakültesi Dergisi, 1(1), 1-21.

Gömleksiz, M. N. (2004b). Kitap okuma alışkanlığına ilişkin bir tutum ölçeğinin geçerlik ve güvenirliği [Validity and Reliability of an Attitude Scale Towards Reading Habit]. Firat Üniversitesi Sosyal Bilimler Dergisi, 14(2), 185-195.

Güneş, F. (1999). Hızlı okuma teknikleri [Speed reading techniques]. Ocak Yayınları.

Heppner, P. P., \& Peterson, C. H. (1982). The development and implications of a personel problem solving inventory. Journal of Counseling Psychology, 29, 66-75.

Kahyaoğlu, M. (2011). Çevre konularıyla ilgili kitap okumaya yönelik tutum ölçeği geliştirme çalışması [Development Study of Attitude Scale towards Reading Book about Environmental Issues]. Ilkögretim Online, 10(3), 1056-1065.

Karakılıç, S., \& Arslan, S. (2019). Kitap okumanın öğrencilerin matematik başarısı ve problem çözme becerisi üzerine etkisi [The impact of book reading on students' problem solving skills and their mathematics success]. Turkish Journal of Computer and Mathematics Education, 10(2), 456-475. https://doi.org/10.16949/turkbilmat.497143

Karsl1, T. A. (2019). Relation Between Metacognitive Awareness and Problem-Solving Abilities in Relation to Age and Parental Educational Status. Ekev Akademi Dergisi, 23(77), 347-361.

Kartal, E., \& Çağlar, Ö. H. (2010). İlköğretim öğrencilerinin okuduklarını anlama ve anlatma düzeylerinin belirlenmesi [Determination of Primary School Students' Reading Comprehension and Expression Levels]. Uluslararası Sosyal Araştırmalar Dergisi, 3(11), 372-380.

Keleş, Ö. (2006). İlköğretim 4. ve 5. Sınıf Öğrencilerinde Kitap Okuma Alışkanlığının İncelenmesi. [Yayımlanmamış Yüksek Lisans Tezi]. Ankara: Gazi Üniversitesi Eğitim Bilimleri Enstitüsü.

Koç, S., \& Müftüoğlu, G. (2008). Dinleme ve okuma öğretimi. http://w2.anadolu.edu.tr/aos/ kitap/IOLTP/2277/unite04.pdf [Date of Access: 21 April 2021]

Kuş, Z., \& Türkyılmaz, M. (2010). Sosyal bilgiler ve Türkçe öğretmeni adaylarının okuma durumları: (İlgi, alışkanlık ve okuma stratejilerini kullanım düzeyleri) [Reading Statuses of Social Studies and Turkish Language Teacher Candidates Their Attention, Habits and Levels of Using Reading Strategies]. Türk Kütüphaneciliği, 24(1), 11-32.

Molfese, V. J., Modglin, A., \& Molfese, L. D. (2003). The Role of Environment in The Development of Reading Skills. Journal of Learning Disabilities, 36, 59-67. https://doi.org/10.1177/00222194030360010701

Odabaş, H., Odabaş, Z. Y., \& Polat, C. (2008). Üniversite öğrencilerinin okuma alışkanlığı: Ankara üniversitesi örnegi [Reading Habit of University Students: The Model of Ankara University]. Bilgi Dünyasl, 9(2), 431-465. https://doi.org/10.15612/BD.2008.313

Olkun, S., Şahin, Ö., Akkurt, Z., Dikkartin, F. T., \& Gülbağcı, H. (2010). Modelleme yoluyla problem çözme ve genelleme: İlköğretim öğrencileriyle bir çalışma [Problem Solving and Generalization Through Modeling: A study on Elementary School Students]. Eğitim ve Bilim, 34(151), 65-73. http://eb.ted.org.tr/index.php/EB/article/view/608

Ortaş, İ. (2014). Türkiye ve Dünyada Kitap Okuma Değerlerinin Karşılaştırması ve Sosyal Yaşamımıza Etkileri [Comparison of Turkey and the World of Reading Book Value and Their Impact on Our Social Life]. Türk Kütüphaneciliği [Turkish Librarianship], 28(3), 323-337.

Özdemirci, F. (1990). Niçin Az Okuyoruz Kamuoyu Araştırması Sonuçlandı [Why We Read Less Public Opinion Survey Concluded] Türk Kütüphaneciliği [Turkish Librarianship], 4(3), 154-155. 
Özsoy, G., Kuruyer, H. G., \& Çakiroglu, A. (2015). Evaluation of students' mathematical problem solving skills in relation to their reading levels. International Electronic Journal of Elementary Education, 8(1), 113-132

Pehlivan, Z., \& Konukman F. (2004). Beden eğitimi öğretmenleri ile diğer branş öğretmenlerinin problem çözme becerisi açısından karşılaştırılması [Comparing the Physical Education Teachers and the Other Branch Teachers in the Aspect of Problem Solving]. Spormetre Beden Eğitimi ve Spor Bilimleri Dergisi, 2(2), 55-60. https://doi.org/10.1501/Sporm_0000000027

Phillip, A. (2020). The reading habit a missing link between literacy and libraries. http://www.pngbuai.com/000general/libraries/literacy-services/READRAB.pdf [Date of Access: 21 April 2021]

Proudfoot, D. E. (2016). The Effect of a Reading Comprehension Software Program on Student Achievement In Mathematics. International Journal of Cognitive Research in Science, Engineering and Education, 4(1), 39-47. https://doi.org/10.5937/IJCRSEE1601039P

Robson, C. (2017). Bilimsel araştırma yöntemleri gerçek dünya araştırmaları [Scientific research methods real world research] (Ş. Çınkır, \& N. Demirkasımoğlu, trans). Anı Yayıncılık.

Saracaloğlu, A. S., Karasakaloğlu, N., \& Yenice, N. (2007). Öğretmen adaylarının problem çözme becerileri ile okuma ilgi ve alışkanlıkları arasındaki ilişki [The Relationship Between Communication and Problem Solving Skills and Reading Interest and Habits of Candidate Teachers']. VI. Ulusal Sınıf Öğretmenliği Sempozyumu, 27-29 Nisan 2007, Eskişehir, 384-389.

Serin, O. (2006). Sınıf öğretmenlerinin problem çözme becerilerinin çeşitli değişkenler açısından incelenmesi [Sınıf öğretmenlerinin problem çözme becerilerinin çeşitli değişkenler açısından incelenmesi]. Eğitim ve Bilim Dergisi, 31(142), 80-88.

Serin, N. B., \& Derin, R. (2008). İlköğretim öğrencilerinin kişilerarası problem çözme becerisi algıları ve denetim odağı düzeylerini etkileyen faktörler [The factors affecting primary school students' perceptions of interpersonal problem solving skills and the levels of locus of control]. Uluslararasl Insan Bilimleri Dergisi, 5(1), 1-18.

Sever, S. (2004). Türkçe ögretimi ve tam öğrenme [Turkish teaching and full learning]. Anı Publishing.

Sevgi, S., \& Karakaya, M. (2021). Ortaokul Öğrencilerinin Okuma Alışkanlığı ve Problem Çözme Becerisinin İncelenmesi [Analysis of Middle School Students Reading Abilities and Problem Solving Abilities]. Gazi Üniversitesi Gazi Eğitim Fakültesi Dergisi, 41(2), 1203-1225. https://doi.org/10.17152/gefad.836544

Şahin, N., Şahin, N. H., \& Heppner, P. P. (1993). The psychometric properties of the Problem Solving Inventory. Cognitive Therapy and Research, 17(4), 379-396. https://doi.org/10.1007/BF01177661

TOKH. (2011). Türkiye okuma kültürü haritası. T.C. Kültür ve Turizm Bakanlığı, Kütüphaneler ve Yayımlar Genel Müdürlüğü.

Ünüvar, A. (2003). Çok Yönlü Algılanan Sosyal Desteğin 15-18 Yaş Arası Lise Öğrencilerinde Problem Çözme Becerisine ve Benlik Saygısına Etkisi [The effect of formal various perceived social support on the self-esteem and problem solving abilities of high school students at the age of fifteen to eighteen]. [Yayınlanmamış Yüksek Lisans Tezi]. Selçuk Üniversitesi Sosyal Bilimler Enstitüsü. http://hdl.handle.net/123456789/4347

Ürün Karahan, B. (2015). Öğretmen adaylarının okumaya yönelik motivasyonlarının çeşitli değişkenler açısından incelenmesi (Kafkas Üniversitesi Örneği) [Kafkas University Pre-Service Teachers' Investigation of Reading Motivation for the Purpose of Several Variables]. Turkish Studies, 10(11), 1569-1586. https://doi.org/10.7827/TurkishStudies.8280

Vilenius-Tuohimaa, P. M., Aunola, K., \& Nurmi, J. E. (2008). The association between mathematical word problems and reading comprehension. Educational Psychology, 28(4), 409-426. https://doi.org/10.1080/01443410701708228

Yavuzer, H. (2013). Presentation. I. Turkey Children and Media Congress Proceedings. Children's Foundation Publications.

Yılmaz, B. (2012). Okuma alışkanlığının okul başarısına etkisi: Ankara Keçiören Atapark İlköğretim Okulu öğrencileri üzerine bir araştırma [The effect of reading habits on school success: A research on Ankara Keçiören Atapark Primary School students]. In Ö. Külcü, T. Çakmak, \& N. Özel (Eds.), Prof. Dr. K. Gülbün Baydur'a armăgan içinde (pp. 209-218). Hacettepe Üniversitesi Bilgi ve Belge Yönetimi Bölümü. http://hdl.handle.net/11655/11695 